\title{
Does Separation of Powers Promote Stability and Moderation?
}

\section{Citation}

Matthew C. Stephenson, Does Separation of Powers Promote Stability and Moderation?, $42 \mathrm{~J}$. Legal Stud. 331 (2013).

\section{Published Version}

doi:10.1086/671055

\section{Permanent link}

http://nrs.harvard.edu/urn-3:HUL.InstRepos:13625569

\section{Terms of Use}

This article was downloaded from Harvard University's DASH repository, and is made available under the terms and conditions applicable to Other Posted Material, as set forth at http:// nrs.harvard.edu/urn-3:HUL.InstRepos:dash.current.terms-of-use\#LAA

\section{Share Your Story}

The Harvard community has made this article openly available.

Please share how this access benefits you. Submit a story.

\section{Accessibility}




\title{
Does Separation of Powers Promote Stability and Moderation?*
}

\author{
Matthew C. Stephenson ${ }^{\dagger}$
}

April 13, 2013

\begin{abstract}
It is often asserted that separation of legislative powers tends to make legislation both more moderate (because concessions to all veto players are needed to secure enactment) and less frequent (because sufficient concessions are sometimes infeasible). The formal analysis in this paper shows this claim to be incomplete, and sometimes incorrect. Although greater separation of powers makes legislation more difficult to enact, it also makes legislation, once enacted, more difficult to repeal. Attenuating the threat of repeal means that when one faction has sufficient power to push through extreme policies, it is more likely to do so than would be the case if legislative power were more concentrated. These two effects cut in opposite directions, and it is difficult to say, as a general matter, which will predominate. Indeed, increasing the fragmentation of legislative power may sometimes increase both the expected frequency and the expected extremism of legislative enactments.
\end{abstract}

*I am grateful to Ethan Bueno de Mesquita, Glenn Cohen, Tiberiu Dragu, Christopher Elmendorf, Justin Fox, Jake Gersen, Jim Greiner, Alex Hirsch, Stuart Jordan, Adriaan Lanni, Elizabeth Magill, John Manning, Ben Roin, Ken Shepsle, Adrian Vermeule, Mark Wu, and participants in the Harvard Law School Conference on Political Risk and Public Law, the University of Virginia Conference on Political Economy and Public Law, and faculty workshops at Harvard University and Fordham University for helpful comments on earlier drafts.

${ }^{\dagger}$ Professor, Harvard Law School, Griswold 509, Cambridge, MA 02138. Email: mstephen@law.harvard.edu 
Tradition has it that in 1789, shortly after Thomas Jefferson returned from France, he and George Washington were arguing over breakfast about the design of the U.S. Constitution. Jefferson is said to have asked Washington why he had agreed to a bicameral legislature with a separate Senate. Washington replied by asking Jefferson why he had just poured his coffee into his saucer. "To cool it," Jefferson answered. "Ever so," said Washington, "we pour legislation into the senatorial saucer to cool it" (Farrand 1966).

Although this story is probably apocryphal, it captures a familiar argument not only for bicameralism, but for the separation of legislative powers more generally. Such separation is thought to encourage moderation and stability, preventing ill-considered proposals from becoming law, and indeed reducing the overall frequency of legislative action. Thus James Madison defended bicameralism in Federalist 62 in part by asserting that because "the faculty and excess of law-making seem to be the diseases to which our governments are most liable," it made sense to provide for a second legislative chamber as an "additional impediment ... against improper acts of legislation." In Federalist 73, Alexander Hamilton made a similar argument in favor of a presidential veto. According to Hamilton, the President's veto power "furnishes additional security against the enaction of improper laws" by establishing "a salutary check upon the legislative body, calculated to guard the community against the effects of faction, precipitancy, or of any impulse unfriendly to the public good, which may happen to influence a majority of that body." Hamilton was careful to acknowledge that the "power of preventing bad laws includes that of preventing good ones," but, like Madison, he argued that on net the "injury that may possibly be done by defeating a few good laws will be amply compensated by the advantage of preventing a number of bad ones."

In making these arguments, Washington, Hamilton, Madison, and other members of the Founding generation were developing an informal (though quite sophisticated) positive political theory of the separation of powers. Some of their arguments emphasized the particular qualities that the occupants of the different offices were likely to possess. So, for example, Representatives would be more majoritarian, while Senators would be more sober and statesmanlike (Macedo 2009). The Founders also sometimes contended that separation of powers would foster more deliberation and would help cultivate civic virtue (Sunstein 1985, 1993b). But there is also a clear strain in their analysis that focuses simply on the idea that a fragmentation of legislative power would make legislation more difficult, would require more compromise, and would therefore lead to a more even distribution, 
across political factions, of the benefits and burdens of any legislation ultimately enacted (Manning 2001, 2007). Under a unitary system, by contrast, a temporary legislative majority — perhaps under the influence of a parochial faction - could enact legislation that benefits certain interests (those holding sway at the moment) at the expense of other groups, or of the general public.

Modern political economy theory has formalized these insights in models that conceive of the lawmaking process in terms of the distribution of agenda-setting, voting, and veto power (Ferejohn and Shipan 1990; Krehbiel 1996, 1998; McCarty 2000). A common conclusion in much of this literature is that an increase in the number of "veto players" (individuals or institutions whose consent is required to enact a new law) tends to make legislation both more moderate (because a statute's proponents must make concessions to all veto players in order to secure its enactment) and less frequent (because sufficient concessions to all veto players might sometimes be infeasible) (Cameron 2000; Cooter 2000; Cox and McCubbins 2001; Riker 1992; Tsebelis 2002; Tsebelis and Money 1997). These models, in other words, seem to confirm the Founders' hypothesis that fragmentation of legislative power will tend to facilitate both moderation (that is, limits on redistribution from one group to another) and stability (that is, preservation of the status quo). In addition to the more obvious forms of fragmentation of legislative power in the U.S. Constitution - such as bicameralism and the presidential veto - other non-constitutional features of the legislative process, such as the committee system and the use in some instances of super-majority rules (for example, cloture votes in the U.S. Senate) can have similar effects (Buchanan and Tullock 1962; Cutrone and McCarty 2006; McGinnis and Rappaport 2002; Shepsle and Weingast 1987).

Whether (or when) these effects are desirable is hotly contested. As noted above, prominent members of the Founding generation, including Hamilton and Madison, viewed legislative overreaching as a greater danger than legislative inertia, and therefore believed that a separation of legislative powers was desirable because it would promote limited (federal) government. ${ }^{1}$ Modern scholars with a more libertarian bent share this view (Calabresi 2001; Clark 2001; Garry 2008).

\footnotetext{
${ }^{1}$ This point should not be overstated. In The Federalist Papers, Madison and Hamilton (and John Jay) were advocating a Constitution that gave the national government much greater power than it had under the Articles of Confederation, and many of the arguments in The Federalist emphasized the need for a stronger national government (McGann 2006). Indeed, in Federalist 22 Hamilton criticized the super-majoritarian features of the Articles of Confederation as inimical to effective governance. Likewise, in Federalist 58 Madison criticized super-majority voting rules as giving minorities too much power to thwart desirable legislation or to "extort unreasonable indulgences" in exchange for acquiescence. Nonetheless, the Founders' belief in the importance of imposing some structural limits on the national legislature, in order to preserve the prerogatives of the States and the liberty of the people, seems to have been sincere and deeply held.
} 
However, at least since the New Deal many critics of the separation of powers have argued that insufficient government action (the result of "gridlock" or "impasse") is often more of a problem than excessive government action (Landis 1936; Levinson 2006; Sunstein 1993a). Moreover, institutions that impede legislative activity do not privilege "limited government" so much as they privilege the status quo, whatever that happens to be (Garrett 2008; McGinnis and Rappaport 2002). If the status quo involves little government regulation, as it arguably did at the time of the Founding (at least at the national level), then constraining legislative activity indeed has libertarian consequences, for good or ill. But if the status quo involves a great deal of government regulation, the fragmentation of legislative power may impede the adoption of deregulatory legislation, with anti-libertarian consequences (Ackerman 2000; Myers 2008).

This paper does not engage directly with these normative questions. Rather, it addresses the positive claim, apparently shared by (almost) all sides in the normative debates, that the fragmentation of legislative power tends, all else equal, to preserve the status quo and to ensure that if legislation is passed, that legislation is "moderate" in the sense that it distributes benefits widely to a larger number of interest groups or factions, rather than conferring large benefits on some groups and large costs on others. Using a simple formal model, the analysis below shows that this positive claim is incomplete, and sometimes incorrect.

This result rests on the familiar observation that political actors care not only about enacting legislation, but about insulating that legislation from future reversal. Indeed, policy insulation is a prominent theme in the political economy literature. Some of the available insulation techniques are institutional: incumbents may try to protect their policies from reversal by delegating to a "hardwired" bureaucracy (Lewis 2003; McCubbins, Noll and Weingast 1987, 1989; Moe 1989, 1990) or by relying on an independent judiciary to enforce the terms of the original legislative bargain (Landes and Posner 1975). However, while these techniques may help insulate legislative bargains against "bureaucratic drift" at the implementation stage, they are less effective in protecting against "legislative drift," because a future legislature could alter the statute itself (Horn and Shepsle 1989).

Another strategy that incumbents may use to insulate their preferred policies is to adopt statutes that are somewhat more moderate - that is, less objectionable to the competing factions that might take power in the future. Policy moderation might achieve insulation in two ways. First, mutual moderation might be sustainable as a cooperative equilibrium in an indefinitely repeated game: each 
major party might explicitly or tacitly agree to adopt moderate policies, and to punish extremism by its rivals with retaliatory extremism (de Figueiredo 2002; Moe and Caldwell 1994; Stephenson 2003). Second, if legislation (including legislation that amends or repeals a prior statute) is costly to enact, then a more moderate statute may be more likely to persist simply because the costs to a rival party of repealing the statute exceed the benefits (Givati and Stephenson 2011; Moe and Caldwell 1994). Thus the implicit threat of repeal in the future may induce moderation in the present, and may sometimes deter legislation altogether if repeal is sufficiently likely that the statute's would-be proponents view the expected benefits of pushing for enactment as lower than the opportunity costs (Ackerman 2000). ${ }^{2}$

As many scholars have observed, however, separation of powers not only makes it more difficult to enact a new statute, but also makes it more difficult to repeal or modify an enacted statute (Crain and Tollison 1979; de Figueiredo 2002; McGinnis and Rappaport 2002; Myers 2008). This means that incumbents with the power to enact a new statute will worry less about future repeal when legislative power is more fragmented. Therefore, greater separation of legislative power may produce two cross-cutting effects on the expected moderation and stability of government policy. First, greater separation of power increases the likelihood of divided government, which makes legislation more difficult to enact and encourages compromise. Second, however, greater fragmentation of legislative power attenuates the threat of repeal. This means that when one faction has sufficient (albeit temporary) control over the government to push through extreme policies in its favor, it is more likely to do so than would be the case if legislative power were more concentrated.

Because these two effects cut in opposite directions, it is difficult to say, as a general matter, which effect will predominate. Indeed, as the subsequent formal analysis will show, increasing the fragmentation of legislative power may increase or decrease both the expected frequency and the expected extremism of legislative enactments. ${ }^{3}$ This conclusion implies that many of the standard

\footnotetext{
${ }^{2}$ Related research has established that in a dynamic legislative bargaining game where proposers or alternatives are randomly selected, a proposer might implement a policy that is closer to the ideal point of the median legislator than the proposer's ideal feasible policy, because the former is more likely to persist for a longer time (Baron 1996; Penn 2009). These models, however, presume the composition of the legislature is fixed (only the identity of the agenda setter changes), whereas the focus here is on how incumbents might use policy moderation as a response to the risk of changes in the composition of the legislature.

${ }^{3}$ Although much of the literature overlooks this observation, two notable exceptions are Ackerman (2000) and de Figueiredo (2002). de Figueiredo (2002) examines an infinitely repeated game in which two interest groups compete for control of the government (a set-up similar to that in Alesina (1987) and related models). He shows that a cooperative equilibrium, in which each group declines to overturn its rival's programs, can be sustained via punishment strategies if the benefits of cooperation are sufficiently high and the groups are sufficiently evenly matched.
} 
defenses and criticisms of the separation of legislative powers may not be well-founded. Indeed, under plausible conditions, a unitary, Westminster-style system will tend to produce stasis or compromise, while a U.S.-style separation-of-powers system will tend to produce periods of relative inactivity punctuated by occasional bursts of extreme, and highly controversial, redistributive legislation that reflects one faction's agenda rather than a broader political compromise.

The paper is organized as follows. Part I presents the basic model and derives equilibria. Part II explores how variation in the fragmentation of legislative power-modeled here as the probability of divided rather than unified government - affects both expected policy stability (that is, the probability that the government will enact and implement new legislation) and expected policy moderation (that is, the degree to which the policy outcome protects the interests of those groups most at risk of suffering major costs from new legislation). Part III discusses empirical and

Although de Figueiredo's main interest is in examining the incentive of parties to insulate their policies through delegation to inefficient bureaucracies, he also shows that separation of powers makes a cooperative equilibrium, based on punishment strategies, more difficult to sustain. Ackerman (2000) makes a somewhat different argument that does not invoke reciprocal punishment strategies. Rather, Ackerman contends that in a Westminster-style parliamentary system, the incumbent party has less of an interest in pushing a bold, ideological policy agenda, because such initiatives are likely to be undone after the next electoral cycle; instead, incumbents will focus on smaller-scale pragmatic initiatives. In contrast, Ackerman continues, in a separation-of-powers system, the government usually faces an impasse, but on those rare occasions when one party has full authority, it will try to press its advantage to maximum extent, rushing through broad, but often largely symbolic, measures consistent with its ideology, knowing that these measures will be difficult to repeal. There are some important differences between the analysis developed in this paper and the arguments of Ackerman and de Figueiredo, but this paper can nonetheless be seen as developing a similar basic insight.

In addition to Ackerman (2000) and de Figueiredo (2002), a few other notable contributions explore related arguments. For example, Alter and McGranahan (2000) argue that although the Senate filibuster requires a super-majority to pass a new law, the filibuster also makes it more difficult to amend a proposed bill, because proposed amendments can also be filibustered. Thus the filibuster can shift power from the median Senator to the proposer, and this can sometimes lead to the enactment of laws that are further from the status quo than the policy that would have prevailed without the filibuster. A related argument appears in the literature on judicial independence, which some have argued can make legislative bargains more durable, thus increasing interest groups' incentive to lobby for favorable legislation (Landes and Posner 1975; Elhauge 1991).

Another related line of argument builds on the observation, developed in the context of social choice theory, that super-majority voting rules (or their functional equivalent) can produce stable equilibrium outcomes in settings where majority rule might otherwise produce intransitive collective preferences. McGann (2006) claims the the stability induced by super-majority rules is inimical to minorities because it will be harder for them to form new coalitions to undo adverse outcomes. Thus McGann - making an argument reminiscent of Dahl (1956), Ely (1980), and Miller (1983) — suggests that in a well-functioning majoritarian democracy there are unlikely to be permanent losers, because minorities can break apart the majority coalition in the future.

In another related but distinct contribution, Rogers (2003) contends that bicameralism might increase rather than decrease legislative production. His argument, however, is also quite different from the one developed in this paper, in that Rogers focuses on the fact that a second chamber can originate as well as reject legislation.

Finally, several scholars have argued that a fragmented legislative process may make it difficult for the legislature to constrain or resist unilateral action by the executive branch, which can give rise to the paradoxical result that greater formal separation of legislative powers may lead to greater de facto concentration of lawmaking power in the executive (Hammond and Knott 1996; Kagan 2001; Moe and Howell 1999). While this hypothesis may have ramifications similar to those generated by the model developed in this paper, the underlying mechanism is quite different. 
normative implications of the analytic results.

\section{The Model}

\section{A. Players, Payoffs, and Order of Play}

There are two parties (or interest groups), which for convenience we will refer to as the "Left" Party $(L)$ and the "Right" Party $(R)$. These parties will decide, through the policymaking process elaborated below, whether to enact and implement a new law. Although at any given time the polity might consider a large number of laws, we will focus on a single representative statute favored by Party L. (One might imagine a parallel process playing out, more or less simultaneously, for any number of statutes, some favored by Party $L$ and others favored by Party $R$, but to simplify things we will consider a single possible statute.) This statute, if enacted and implemented in the form most preferred by Party $L$, would give Party $L$ a net benefit of $B>0$, but would impose a net cost of $C>0$ on Party $R$, where $B$ and $C$ are common knowledge and exogenous.

For example, suppose the statute under consideration is a pollution control measure. In this case, Party L's constituents are those who would benefit from improved environmental quality (such as conservationists, public health advocates, and firms that specialize in "clean" technologies) while Party $R$ represents constituencies, such as polluting firms and producers of "dirty" fuels, that would bear most of the economic burdens associated with the proposed pollution controls. Or, we might imagine that the law under consideration is an international treaty that would reduce tariff barriers, to the benefit of Party L's supporters (such as consumers and export-oriented firms) and to the detriment of Party $R$ 's supporters (import-competing firms). This latter example highlights the fact that the labels "Left" and "Right" are merely for expositional convenience, and might not correspond to conventional "liberal" and "conservative" ideologies or to organized political parties. ${ }^{4}$

Although $B$ and $C$ capture the welfare consequences of the statute if it is enacted in "pure" form (that is, the form that gives proponents their highest feasible payoff), it is possible to modify the statute so that its distributional impact is more equitable. In particular, Party $L$ may incorporate

\footnotetext{
${ }^{4}$ Indeed, instead of thinking of these two players as "parties," one can instead conceive of them simply as the "proponents" and "opponents" of any given piece of legislation. Understood that way, it is clear that these "parties" may in fact be coalitions of multiple factions - or, in multiparty parliamentary systems, of multiple parties-and indeed this particular cleavage may cut across party lines.
} 
into the statutory proposal a "transfer," $T \geq 0$, that increases the payoff of the statute to Party $R$ by $T$ but reduces the payoff to Party $L$ by $\lambda T$, where $\lambda>0$ captures the marginal cost to Party $L$ of making the compromises that mitigate the impact of the statute on Party $R$. For example, suppose that the government is considering an environmental protection statute. The most effective version of the statute would set emissions caps on pollution sources, but would allow them to comply through whatever means are most efficient. This version of the statute, however, would impose significant costs on producers of dirty coal, because the cheapest way for most sources to achieve compliance with the statute would be to switch to cleaner fuels. An alternative version of the statute might require sources to use specific pollution control technologies instead of meeting particular emissions targets. Doing so would mute the adverse impact of the statute on dirty coal producers. This alternative statute would not be as good for proponents, as well as more costlymandating particular technologies is less effective in reducing pollution - but it is better than no statute at all. ${ }^{5}$ Enacting the statute without concessions is equivalent to setting $T=0$.

The two-period policymaking process proceeds as follows. At the start of the first period, an election determines control of the government's legislative institutions. For simplicity, and to focus attention on the strategic behavior of politicians once in office, the model treats the election as an exogenous lottery: with probability $p(1-\pi)$, where $p \in(0,1)$ and $\pi \in[0,1]$, Party $L$ has unified control over the government, meaning that Party $L$ can enact a new statute unilaterally; with probability $(1-p)(1-\pi)$, Party $R$ has unified control. With probability $\pi$, the government is divided, which means that enacting new legislation requires the consent of both parties. ${ }^{6}$

The $\pi$ parameter is crucial to the analysis, so it is worth unpacking a bit more. This parameter seeks to capture, in reduced form, the degree of de facto "legislative fragmentation" or "separation of powers." One can imagine $\pi$ as an increasing function of, among other things, the number of legislative veto gates created by the constitution and/or the subconstitutional rules of the legislative process, as will as the prevalence of super-majority rules or other measures that may give minority factions blocking power. The basic idea is that a higher $\pi$ indicates a higher probability that opposing parties or factions will all wield enough legislative power that no one faction can enact its preferred policies unless it is able to make sufficient concessions to its opponents. Thus

\footnotetext{
${ }^{5}$ This stylized example is based on the history of the federal Clean Air Act (Ackerman and Hassler 1981).

${ }^{6}$ The "divided government" terminology, though expositionally useful, is potentially misleading. As noted earlier, the relevant interest groups for a given statute might not correspond to political parties.
} 
a pure "unitary" system (perhaps approximated by a Westminster-style parliamentary democracy, or a system in which a powerful chief executive effectively controls the lawmaking process) would be characterized by $\pi=0$. In such systems, whichever faction wins control of the single lawmaking body can implement its agenda without having to worry about an opposition veto. The opposite polar case, in which $\pi=1$, might correspond (approximately) to a "consociational" system (Lijphart 1977), in which all major factions have an effective veto over new legislation. A system with multiple independently elected legislative branches, or a legislature that operates under some form of super-majority rule, would have some intermediate value of $\pi$, with higher values of $\pi$ implying greater fragmentation of legislative power. For example, consider a system with a bicameral legislature, where each of two parties has a 50 percent chance of winning control of each chamber, assuming for simplicity that those probabilities are statistically independent. In this case, we would have $p=0.5$ and $\pi=0.5$ : in each new lawmaking period, there is a 25 percent chance of unified Left Party control, a 25 percent chance of unified Right Party control, and a 50 percent chance that each party will control one chamber but not the other. That last possibility implies that compromise is required to enact any new laws (or to repeal any existing ones). If there were three veto players - say, a House, a Senate, and a President - and each party's odds of winning control of any given branch remained 50-50 (and statistically independent), then we would have $p=0.5$ and $\pi=0.75$, because in this setting the odds that a single faction will win control of all three branches is only 1 in $4 .^{7}$

After the first-period election, Party $L$ may propose the new statute (including in the proposal a transfer, $T$ ), or may take no action. If Party $L$ has unified control over the government, it may enact the statute unilaterally; if not, it can enact the statute only if Party $R$ consents. ${ }^{8}$ Enacting the statute entails an additional cost to Party $L$ of $K_{E} \geq 0$, which can be thought of as a reduced

\footnotetext{
${ }^{7}$ The assumption of statistical independence in these examples is unrealistic, but the modeling framework here can accommodate correlations (both positive and negative) in the probabilities that any one faction controls different lawmaking bodies. If the fortunes of a party's candidates for different offices tend to rise or fall together, then $\pi$ would tend to be lower, all else equal; if voters seem to prefer to "split their tickets" (Mebane 2000) then $\pi$ would tend to be higher.

${ }^{8}$ The assumption that Party $L$ may propose the statute even if Party $R$ has unified control may be unrealistic in some systems, because the dominant party might not allow the opposition to introduce any proposals (even those that would pass). The model could easily be altered to accommodate that sort of agenda control by assuming that if Party $R$ has unified control in the first period, the game ends (or, alternatively, the game only starts when there is a first-period electoral result that would allow Party $L$ to place a proposal on the agenda). While such a modification would alter the analysis somewhat, the main qualitative results would hold. Moreover, because the selection of a statute favored by Party $L$ was an arbitrary expositional assumption, one could interpret the model as applying to a different statute, favored by Party $R$, if Party $R$ gets unified control in the first period.
} 
form expression of the opportunity costs of the time, effort, and political capital required to develop a statutory proposal, get it on the crowded legislative agenda, and secure its passage. A simple way to micro-found this assumption might be to imagine that each party can allocate one unit of effort per period either to legislating or to some alternative activity, such as retail constituency service, with the latter providing a utility benefit of $K_{E} \cdot{ }^{9}$ We restrict attention to cases in which $B>K_{E}$, as these are the only cases in which Party $L$ would ever make a proposal.

The fixed cost of legislative action is a crucial feature of the analysis. While it is presumably uncontroversial that there is an opportunity cost (often a significant opportunity cost) associated with working on any given legislative initiative, modeling this cost as fixed and exogenous comes at some cost in terms of realism. In particular, one might plausibly argue that the enactment cost ought to be a function of the substantive policy-though it is not clear a priori whether the enactment cost ought to be increasing, decreasing, or non-monotonic in the extremism of the policy. ${ }^{10}$ While a richer model might incorporate variable enactment costs, as a first cut it seems reasonable to take them as fixed, particularly since in many settings the main sources of the enactment cost (e.g., time spent working on legislation rather than constituency service) are plausibly exogenous to the content of the policy. Note also that the enactment cost is not a function of whether the government is unified or divided; this may at first seem unrealistic, but the obstacles that divided government may create for legislation are captured by the possible need for the transfer, $T$, in order to get the other party to go along.

At the beginning of the second period there is another election, which may result in a change in control of the legislative branch(es) of the government. For simplicity, assume that the respective probabilities of Left Party unified government, Right Party unified government, and divided government in the second period are the same as the probabilities of each of these configurations in the first period: $p(1-\pi),(1-p)(1-\pi)$, and $\pi$, respectively. Thus the probabilities of different configurations of political control in the second period are independent of first-period control and

\footnotetext{
${ }^{9}$ To economize on notation, the model assumes that the enactment cost $K_{E}$ is incurred only if the statute is actually enacted. In the real world, a portion of these costs would be incurred whether or not the statute passes. However, in equilibrium Party $L$ proposes a statute only if it is certain to pass, which means that it is analytically irrelevant whether the cost $K_{E}$ is incurred before or after enactment.

${ }^{10}$ Of course, to some extent variable costs associated with the level of policy extremism are already built into $\lambda$, the "shadow price" of policy moderation. If one thought, for example, that more moderate policies are less costly for the dominant coalition to enact (and if one is willing to make the further heroic assumption that this relationship is linear), then one can simply adjust $\lambda$ so that any given moderating transfer to $R$ comes at a lower cost to Party $L$.
} 
of the policy choice. This admittedly unrealistic assumption greatly simplifies the exposition of the principal qualitative result that the model is meant to elucidate. ${ }^{11}$ The assumption may be most substantively plausible for the mine-run of statutes (including many with significant policy consequences) that have a marginal impact on electoral outcomes relative to exogenous shocks (such as the state of the economy). ${ }^{12}$ However, the assumption is most problematic when the policy choice in question may have significant electoral consequences for incumbent lawmakers, as will often be the case for the most important, high-profile issues. ${ }^{13}$ Even in these cases, though, the simplifying assumption that second-period election probabilities are independent of first-period policy choice, despite its lack of realism, is relatively benign for present purposes, given that this model is meant to explore how the uncertainty of future electoral outcomes affects current decision-making. Although the electoral consequences of the first-period choice might make different levels of extremism more or less attractive, and might likewise affect the strength of a party's interest in insulating its measures from future repeal, so long as those effects are not so large that they swamp all other considerations, then the qualitative results identified in the simplified model presented here would continue to obtain, though perhaps in attenuated (or enhanced) form. ${ }^{14}$

If the first-period government enacted the statute, the second-period government can choose

\footnotetext{
${ }^{11}$ Other contributions explore how separation-of-powers interacts with electoral incentives (Fox and Van Weelden 2010; Persson, Roland and Tabellini 1997; Stephenson and Nzelibe 2010; Vlaicu 2008); the analysis in this paper can be seen as complementary to these efforts, though fully integrating their insights is a task for future research.

${ }^{12}$ This is not to say that real-world legislators will ever ignore completely the electoral consequences of their actions, even when the electoral impact of any given decision may seem marginal (Arnold 1990; Kagan 2001). Rather, the point is that for many issues, the short-term electoral consequences will be sufficiently small, relative to policy considerations, that the assumption that reelection probabilities are exogenous does not entail too great a loss of descriptive realism. This is particularly so when lawmakers deal with large numbers of issues, each of which has only a small impact on their electoral prospects (Berry and Gersen 2008).

${ }^{13}$ It is worth noting, however, that the relationship between the "extremism" of the policy choice (as that term is used here) and the parties' respective probabilities of reelection is not at all clear. A plausible intuitive hypothesis is that more extreme redistributive policies should reduce the incumbents' probability of reelection, given the evidence that most voters (at least in the United States) are centrist and prefer more moderate policies (Alesina and Rosenthal 1995; Mebane 2000; Mebane and Sekhon 2002). However, under some circumstances the electoral benefits of "turning out the base" - by enacting "extreme" policies that energize a party's core constituents - may outweigh the electoral costs of reducing the party's appeal to centrist voters, despite the fact that the latter are more numerous (Fiorina 1999; Glaeser, Ponzetto and Shapiro 2005; McGinnis and Rappaport 2006). It is therefore not clear whether the the correlation between the extremism of the policy and Party L's electoral fortunes should be positive, negative, or non-monotonic. It is partly for this reason that it seems reasonable, at least as a first cut, to bracket this problem and treat the election probabilities as exogenous, if only to establish a baseline.

${ }^{14}$ For example, if policy extremism decreases the chance that the incumbent will be reelected, then passing an extreme statute becomes less attractive relative to passing a more moderate statute, both because office-holding is intrinsically valuable and because it is more likely that an extreme statute will be repealed due to a change in partisan control. As the subsequent analysis will suggest, in this case increasing the degree of legislative fragmentation, by reducing the risk of repeal, will make the extreme statute relatively more attractive, just as it does in the case where electoral probabilities are exogenous.
} 
whether to repeal it. If Party $R$ has sole control of the second-period government, it can repeal the statute unilaterally; otherwise, Party $R$ cannot repeal the statute without Party $L$ 's consent. If Party $R$ pushes through a repeal, it bears an additional cost of $K_{R} \geq 0$, which we can think of as the opportunity cost of pressing for repeal (as opposed to working on other activities, such as retail constituency service) as well as any political costs that advocating repeal might entail. ${ }^{15} \mathrm{We}$ restrict attention to cases where $C>K_{R}$.

Both players then receive their payoffs. If no statute was enacted in the first period, both parties receive a status quo payoff normalized to 0 . If the statute was enacted in the first period and implemented (that is, not repealed) in the second period, then Party $L$ 's net payoff is $B-\lambda T-K_{E}$, while Party $R$ 's net payoff is $T-C$. If the statute was enacted in the first period but repealed in the second period, then Party $L$ 's net payoff is $-K_{E}$, while Party $R$ 's net payoff is $-K_{R}$. These assumptions imply that the statute does not have any policy effects until the conclusion of the second period. That simplifying assumption may be substantively appropriate in some circumstances, as when key statutory provisions do not take effect until several years after enactment (Gersen and Posner 2007). It would also be appropriate, at least as a first approximation, if the parties have long time horizons (i.e., low discount rates). In most cases, though, policies have immediate effects on lawmakers' welfare - both in terms of policy impact, and also in terms of the independent signaling or "position taking" effect that supporting or opposing a policy may have on a lawmaker's reputation with various constituencies (Mayhew 1974). That said, the main qualitative results of the analysis below would continue to hold, albeit with some attenuation, in an alternative model where some of the statutory benefits and costs are realized in the first period, as long as these first-period effects are not too large relative to second-period effects. Rather than including an additional term to represent first-period benefits and costs (the qualitative effects of which would be obvious, and which would not affect the comparative statics of interest), the model simply ignores first-period

\footnotetext{
${ }^{15}$ As with $K_{E}$, the model assumes Party $R$ incurs cost $K_{R}$ only if the statute is actually repealed, but the results would be identical if some of the cost were incurred when repeal is proposed, since in equilibrium Party $R$ only proposes repeal when it anticipates success. Also as with $K_{E}$, the model assumes $K_{R}$ is constant and independent of the extremism of the statute, an assumption that, while admittedly unrealistic, greatly simplifies the analysis.

In addition, it is worth observing that the model does not assume $K_{E}=K_{R}$. It is easy to imagine a variety of reasons why these costs may differ. For example, it is plausible that it is much more difficult, in terms of time and effort, to design a new policy program than to eliminate one that already exists - a bill enacting a new program may be thousands of pages, while a bill repealing that program may be a few paragraphs. This would imply $K_{R}<K_{E}$. On the other hand, the enactment of a statute may create vested interests that significantly raise the political costs of repeal (Coate and Morris 1999; Pierson 2001). This could imply $K_{R}>K_{E}$. The model can accommodate either possibility.
} 
effects. ${ }^{16}$ The reader should keep in mind, however, that very large first-period effects would tend to undermine the principal reason why separation of powers might (counter-intuitively) sometimes induce moderation or inaction. Thus this model should be understood as applying principally to those issues for which long-term effects are important relative to short-term effects. Major regulatory initiatives would seem to have that property in many cases, though other policies may not. ${ }^{17}$

In sum, the game is as follows:

Step 0: The first election is held. With probability $p(1-\pi)$, Party $L$ has sole control over the government; with probability $(1-p)(1-\pi)$, Party $R$ has sole control; and with probability $\pi$, the government is divided.

Step 1: Party $L$ can choose either to propose a statute or to do nothing. If Party $L$ chooses to do nothing, the game proceeds immediately to Step 6. If Party $L$ chooses to propose a statute, Party $L$ also chooses a transfer, $T$.

Step 2: If Party $L$ has sole control, the statute proposed at Step 1 is automatically enacted. Otherwise, Party $R$ chooses whether to accept the proposal. If Party $R$ rejects the proposal, the status quo remains in effect, and the game proceeds immediately to Step 6. If Party $R$ accepts the proposal, the statute is enacted, and Party $L$ incurs an enactment cost of $K_{E}$.

Step 3: There is a second election. With probability $p(1-\pi)$, this election gives Party $L$ unified control of the government; with probability $(1-p)(1-\pi)$, the election gives Party $R$ unified control; and with probability $\pi$, the government is divided.

Step 4: Party $R$ decides whether to propose repeal of the statute. If Party $R$ chooses not to do so, the statute is implemented and the game proceeds immediately to Step 6.

\footnotetext{
${ }^{16}$ Alternatively, it is possible to imagine some first-period effects as already implicitly incorporated into the model's existing parameters, so long as those effects are not too large. For example, for Party L, one can think of the enactment cost $K_{E}$ not simply as the opportunity costs of enactment, but as the opportunity costs of enactment minus whatever first-period benefits Party L would receive from enacting the statute. The model's assumption that $K_{E} \geq 0$ implies that those first-period benefits are not large enough for Party L ever to enact a statute that has only first-period benefits. For Party R, first-period effects cannot be incorporated into existing model parameters quite so straightforwardly, but it is clear that the existence of first-period costs would imply only that Party $\mathrm{R}$ would demand a larger minimum transfer $T$ to consent to the enactment of Party L's proposed statute, and would not otherwise affect Party R's behavior.

${ }^{17}$ Note also that the model applies only to those policy initiatives that, once enacted, remain in force. Policies that must be re-approved on a regular basis, such as discretionary spending allocations or statutes with sunset clauses, would have only first-period effects, and so the analysis here would not apply.
} 
Step 5: If Party $R$ has unified control over the government, it chooses whether to repeal the statute. Otherwise, Party $R$ may propose repeal but the proposal must be approved by Party $L$. If approval is not granted, the statute remains in effect. Repealing the statute costs Party $R$ an additional $K_{R}$.

Step 6: Both players receive their policy payoffs. If no statute was ever enacted, or if a statute was enacted but subsequently repealed, both players receive a status quo policy payoff of 0 . If the statute is enacted and retained, Party $L$ receives a policy payoff of $B-\lambda T$, while Party $R$ receives a policy payoff of $T-C$. (These policy payoffs do not include any legislation costs, $K_{E}$ and $K_{R}$, that the parties may have also incurred.)

\section{B. Equilibrium}

This is a sequential finite-period game with perfect information, so one can use backward induction to identify the subgame perfect Nash equilibrium for different parameter values.

In the second period, if Party $L$ has sole control over the government (which occurs with probability $p(1-\pi)$ ), or if the government is divided (which occurs with probability $\pi$ ), the statute will be retained and implemented. ${ }^{18}$ Retention of the statute gives Parties $L$ and $R$ second-period payoffs of $B-\lambda T$ and $T-C$, respectively. However, if Party $R$ has sole control of the second-period government (which occurs with probability $(1-p)(1-\pi)$ ), then Party $R$ can unilaterally repeal the statute. If Party $R$ chooses to do so, then its second-period payoff is $-K_{R}$, while Party $L$ 's second-period payoff is 0 . If Party $R$ leaves the statute in place, then its second-period payoff is $T-C$, while Party $L$ 's second-period payoff is $B-\lambda T$. This implies that if Party $R$ has sole control of the second-period government, it will repeal the statute if but only if $T<C-K_{R}$. Thus the minimum transfer required to induce Party $R$ to leave the statute in place is $C-K_{R} \cdot{ }^{19}$

\footnotetext{
${ }^{18}$ This claim assumes that $B \geq \lambda T$. This is always true in equilibrium, since a statute with $B<\lambda T$ would give Party $L$ a negative policy payoff, and Party $L$ would never have an incentive to adopt such a statute.

The assertion that the statute would always be retained if Party $L$ can block second-period repeal also assumes that Party $R$ cannot offer Party $L$ a side payment. If Party $R$ could offer a (take-it-or-leave-it) side payment in exchange for consent to a repeal, this would (weakly) improve Party $R$ 's expected payoff, but it would not affect Party L's second-period payoff, because the side payment would be just enough to offset Party L's expected gain from the statute. Thus Party L's first-period incentives would be unaffected. There are other possibilities, however. For example, if Party $L$ could dictate the terms of the side payment, there could be equilibria in which Party $L$ enacts a statute with the purpose of extracting side payments from Party $R$ in exchange for repeal. These and other possibilities are left for future research.

${ }^{19}$ The analysis makes the tie-breaking assumption that if Party $R$ is indifferent between repealing and retaining the statute, it will not propose repeal.
} 
Now consider the first period. Consider first the case in which Party $L$ has unified control over the first-period government, and so can enact a new statute unilaterally. In this case, Party $L$ has three (relevant) choices. First, Party $L$ could take no action, guaranteeing itself a status quo payoff of 0 . Second, Party $L$ could enact the statute and set $T=0$. We will refer to this version of the statute as an "extreme" statute, in that it confers the largest feasible benefit $(B)$ on Party $L$ and the largest possible cost $(C)$ on Party $R$. An extreme statute, however, will be repealed if Party $R$ takes over in the second period, because of the assumption that $C>K_{R}$. Thus Party $L$ 's expected net payoff from enacting an extreme statute is $[1-(1-p)(1-\pi)] B-K_{E}$. Third, Party $L$ could enact the statute but set $T=C-K_{R}$. We will refer to this version of the statute as a "moderate" statute. A moderate statute will always be retained in the second period, even under unified Right Party government, because even though such a statute imposes net costs on Party $R$, these costs are no larger than the costs of repeal. Therefore, enacting a moderate statute gives Party $L$ a net utility of $B-\lambda\left(C-K_{R}\right)-K_{E}$. Note that Party $L$ never has an incentive to enact a statute with $T \in\left(0, C-K_{R}\right)$, as doing so sacrifices policy benefits without foreclosing the possibility of repeal. Likewise, when Party $L$ has unified control over the government, it never has an incentive to enact a statute with $T>C-K_{R}$, as this would entail making more concessions than necessary to guarantee the implementation of the statute. In the unified Left Party government case, then, we can focus on Party L's choice among three options: (1) the status quo, (2) the extreme statute $(T=0)$, and $(3)$ the moderate statute $\left(T=C-K_{R}\right)$.

It will be helpful, in characterizing Party $L$ 's equilibrium choice among these three options, to define $\bar{\pi}=\max \left\{1-\frac{B-K_{E}}{(1-p) B}, 1-\frac{\lambda\left(C-K_{R}\right)}{(1-p) B}\right\}$. Algebraic manipulation of the expected utility expressions in the preceding paragraph reveals reveals that if $\pi \geq \bar{\pi}$, Party $L$ will adopt an extreme statute under unified first-period government. If $\pi<\bar{\pi}$ and $B-K_{E} \geq \lambda\left(C-K_{R}\right)$, Party $L$ will enact the moderate statute, while if $\pi<\bar{\pi}$ and $B-K_{E}<\lambda\left(C-K_{R}\right)$, Party $L$ will take no action. ${ }^{20}$ The intuition for the significance of $\bar{\pi}$ is that if Party $L$ has unified control over the government in the first period, only the threat of repeal could deter Party $L$ from enacting an extreme statute. This threat is weaker if divided government in the second period is more likely, because under divided government Party $L$ can block any attempted repeal. If $\pi<\bar{\pi}$, the threat of repeal is sufficient to

\footnotetext{
${ }^{20}$ The analysis makes the tie-breaking assumptions that: (1) if Party $L$ is indifferent between a moderate statute and an extreme statute, it will choose the extreme statute; and (2) if Party $L$ is indifferent between enacting a new statute and the status quo, it will choose to enact the statute.
} 
deter Party $L$ from enacting an extreme statute. The question then becomes whether Party $L$ will enact a moderate statute or nothing at all. This choice depends simply on whether Party $L$ 's net benefit from a moderate statute $\left(B-\lambda\left(C-K_{R}\right)-K_{E}\right)$ is positive or negative. ${ }^{21}$

Now consider the case in which the first-period government is either divided or under Party $R$ 's control. In this case, Party $R$ can guarantee itself a status quo payoff of 0 by vetoing Party $L$ 's legislative proposal. Therefore, to convince Party $R$ to go along with enactment of the new statute, Party $L$ must offer a transfer of at least $T=C .{ }^{22}$ We will refer to a statute containing a transfer of $T=C$ as a "consensus" statute, because this proposal is enacted with the support of both parties (even though the net benefit is strictly positive only for Party $L$ ). A consensus statute is always retained in the second period, even if Party $R$ has sole second-period control, because it is never worthwhile for Party $R$ to incur the costs of repeal $\left(K_{R}\right)$ in order to obtain a status quo payoff $(0)$ that is equal to Party $R$ 's net payoff under the consensus statute $(T-C=0)$. Thus, under divided first-period government, Party $L$ has two (meaningful) choices: (1) it can secure enactment of a consensus statute $(T=C)$ for a net payoff of $B-\lambda C-K_{E}$, or (2) it can take no action, for a status quo payoff of 0 . Party $L$ prefers the former if but only if $B-K_{E} \geq \lambda C{ }^{23}$

\section{Institutional Comparisons}

The primary questions of interest concern how the probability of divided government $(\pi)$ affects two outcome variables: (1) the expected frequency of legislative action, and (2) the expected

\footnotetext{
${ }^{21}$ The assumptions that $B>K_{E}$ and $C>K_{R}$ guarantee that $\bar{\pi}<1$. However, some feasible parameter values would generate $\bar{\pi} \leq 0$, which would imply that Party $L$ would always adopt an extreme statute when possible. This is the case if the maximum statutory benefit to Party $L(B)$ is sufficiently large relative to the enactment cost $\left(K_{E}\right)$ but sufficiently small relative to the cost of the minimum transfer necessary to insulate the statute from reversal $\left(\lambda\left(C-K_{R}\right)\right)$. More precisely, if $B \in\left[\frac{K_{E}}{p}, \frac{\lambda\left(C-K_{R}\right)}{1-p}\right]$, then the probability of divided government does not affect how a first-period unified government would behave. This is the case implicitly assumed by the standard analysis of separation of powers. The analysis in this paper indicates that these results may not hold if enactment costs are sufficiently large $\left(K_{E}>p B\right)$, or if the costs of the transfers needed to insulate the statute are sufficiently small $\left(\lambda\left(C-K_{R}\right)<(1-p) B\right)$. If either of those conditions hold, then $\bar{\pi} \in(0,1)$, which means that for some feasible values of $\pi$ a first-period unified government would enact an extreme statute, but for other feasible values of $\pi$ it would not.

${ }^{22}$ In this model Party $L$ can make a take-it-or-leave-it offer to Party $R$. There are, of course, many other ways that the potential surplus of the statute might be divided, but the simple structure employed here is a reasonable and analytically simple way to develop the main qualitative results, one that is consistent with canonical models of legislative bargaining (Baron and Ferejohn 1989). More substantively, one might suppose that the different parties have different legislative priorities; Party $R$ might thus be willing to concede agenda-setting power on this statute to Party $L$ because Party $R$ is assuming the agenda-setting role on other proposals.

${ }^{23}$ Under divided government, Party $L$ has no incentive to propose a statute with $T \neq C$. Any proposed statute with $T<C$ would not be enacted, while any proposed statute with $T>C$ would entail more concessions than are necessary to secure enactment.
} 
extremism or moderation of government policy. As noted in the introduction, a standard (though not universal) hypothesis is that institutions that induce a greater fragmentation of legislative power-for example, bicameralism, an executive veto, super-majority rules, or a strong committee system - will, all else equal, tend to reduce the frequency of legislation overall and to induce greater moderation of government policy (that is, to induce compromises that result in statutes that are somewhat better for those parties initially in opposition, and somewhat less good for proponents). These hypotheses flow from the natural and intuitive observation that a separation of powers makes it more difficult to enact a new statute because it is more likely that the statute's opponents will control at least one of the "veto gates" in the legislative process, which in turn will force the statute's proponents either to make significant concessions or to abandon the legislative effort altogether.

This observation is not wrong, but it is critically incomplete. The model developed in Part I indicates that changes in $\pi$ may have two effects, which can cut in opposite directions. First, as the conventional argument sketched above suggests, an increase in $\pi$ increases the probability that the first-period government will be divided rather than unified. And, indeed, under divided government the proponents of a new statute cannot pass that statute unless they are willing to make significant concessions to the statute's opponents - concessions that make the opponents at least as well off under the new statute as they would have been under the status quo. However, an increase in $\pi$ may have a second effect as well. If $\bar{\pi} \in(0,1)$, then it is possible that an institutional change might increase $\pi$ from a value below $\bar{\pi}$ to a value above $\bar{\pi}$. If this occurs, then Party $L$ 's first-period equilibrium strategy will change. In particular, when $\pi<\bar{\pi}$, a unified Left Party government would either adopt a moderate statute or retain the status quo, but if $\pi$ increases to a value above $\bar{\pi}$, Party $L$ would take advantage of unified first-period government to enact an extreme statute instead. ${ }^{24}$ Most discussions of separation-of-powers institutions tend to neglect this second effect. ${ }^{25}$

\footnotetext{
${ }^{24}$ If $\bar{\pi} \leq 0$, this second effect would not arise, because it would be the case that $\pi \geq \bar{\pi}$ for all permissible values of $\pi$. In that case, the conventional account of separation-of-powers institutions would be unproblematic. The analysis in the main text focuses on the more interesting case in which $\bar{\pi} \in(0,1)$.

${ }^{25}$ As noted earlier, the most prominent exceptions to this generalization about the existing literature are Ackerman (2000) and de Figueiredo (2002). While the analysis here owes an obvious intellectual debt to these contributions, it also differs in several ways.

With respect to de Figueiredo (2002), although the qualitative result that separation of powers can increase moderation is similar, the mechanism is quite different, in that de Figueiredo considers an infinite-horizon game in which cooperation is sustained via punishment strategies. The distinct mechanisms highlighted by this paper and by de Figueiredo (2002) are not mutually exclusive; rather, they can be seen as complementary.

The mechanism suggested by Ackerman (2000) appears somewhat closer to the mechanism driving the analysis in this paper. There are, however, two important differences (in addition to the fact that Ackerman does not formalize his insight). First, Ackerman does not attempt to assess the effect of separation of powers on the expected stability or
} 
To pursue this idea further, let us compare a "unitary" system in which $\pi=0<\bar{\pi}$ to a "separation-of-powers" (SOP) system in which $\pi=\pi^{*} \geq \bar{\pi}$ (that is, a SOP system in which the probability of divided government is high enough to affect Party L's equilibrium choice under first-period unified government). ${ }^{26}$ We are interested in comparing these institutional regimes with respect to: (1) the probability that new legislation is enacted in the first period, as well as the probability that new legislation is both enacted and retained; and (2) the "moderation" or "extremism" of the legislative outcome. This latter variable is defined simply as the expected cost of the legislative policy outcome to Party $R$. The higher this cost, the more "extreme" is the legislative outcome. ${ }^{27}$ Although there are other ways one might define policy moderation/extremism, this definition seems most in keeping with prominent arguments about the effect of separation of powers, namely, that it will protect the interests of parties that stand to lose from new legislation, either by blocking the legislation or by inducing the legislation's proponents to offer more concessions.

The analysis is complicated by the fact that the players' equilibrium strategies depend not only on $\pi$, but on the other parameters as well. We will therefore consider separately two cases. In the

moderation of government policy. Indeed, Ackerman's analysis seems to imply that on average, U.S.-style separation of powers will produce greater policy stability (or, in his terms, "impasse"), even though on rare occasions of unified government there will be flurries of activity. As the analysis below shows, however, under plausible conditions even the expected stability and moderation of government policy can decrease as the fragmentation of legislative power increases. Second, Ackerman focuses primarily on features of legislation other than its distributional effects-in particular: (1) whether the legislation is pragmatic or symbolic, and (2) whether the legislation is narrowly legalistic or whether it delegates more open-ended authority to those charged with implementation. Ackerman hypothesizes that unitary Westminster-style systems tend to produce practical programs that provide immediate and tangible benefits to voters, while U.S.-style separation of powers encourages parties that find themselves in the rare position of full control to enact legislation that is both heavily symbolic (because it is easier to deliver symbolic as opposed to concrete results before the next election) and extremely legalistic (because detailed legal requirements are harder to overturn or redirect than are more open-ended programs administered by the bureaucracy). (This latter claim is similar to the "intentional bureaucratic inefficiency" argument developed most prominently by Moe (1989, 1990), and critiqued by de Figueiredo (2002).) While the analysis presented here is compatible with these hypotheses, it focuses instead on expected distributional consequences. Indeed, perhaps contra Ackerman, the model developed here implies that under unified government the incumbents' incentives are to enact statutes with significant substantive effects, rather than those that are mostly symbolic. Also, the analysis here suggests an important caveat to Ackerman's claim that governments in unitary systems will tend to produce incremental, practical legislation: if the enactment costs of such legislation are sufficiently high relative to the benefits (to the incumbent party), the result may be to discourage such legislation altogether.

${ }^{26}$ Increasing $\pi$ from 0 to any value below $\bar{\pi}$ increases the probability of divided government without affecting equilibrium behavior under either unified or divided government. Likewise, increasing $\pi$ from $\bar{\pi}$ to any value above $\bar{\pi}$ increases the probability of divided government without changing equilibrium behavior.

${ }^{27}$ This definition implies that the most moderate possible equilibrium outcome is one that gives Party $R$ its status quo payoff (0). In principle, a statute that provided equal benefits to both parties - that is, a statute with $T=\frac{B+C}{1+\lambda}$, such that each party receives a policy payoff of $B-\lambda T=T-C$-would be maximally moderate, but such statutes are never enacted in equilibrium (except in the special case where $T=C=\frac{B}{\lambda}$, in which case both parties get a policy payoff of 0). Also, when interpreting the qualitative discussion of the main results, it is important to keep in mind that "moderation" here does not mean moderation in some objective or absolute sense; rather, it means moderation in the degree of change from the status quo. 
first case, $B-K_{E}<\lambda\left(C-K_{R}\right)$. This condition implies that in a unitary system $(\pi=0)$, a united Left Party government would not enact the statute in the first period, even though (by assumption) the policy benefits of the statute $(B)$ exceed the opportunity costs of enactment $\left(K_{E}\right)$. The reason is that even if Party $L$ has sole control of the first-period government, it recognizes that Party $R$ might well assume control in the second period, and if that occurs then an extreme statute would be repealed. This threat of repeal is significant enough to deter Party $L$ from enacting an extreme statute, as the probability-discounted benefit of enacting the extreme statute $(p B)$ is smaller than the opportunity cost of enactment $\left(K_{E}\right) .{ }^{28}$ Furthermore, the condition that $B-K_{E}<\lambda\left(C-K_{R}\right)$ implies that the costs to Party $L$ of the concessions necessary to insulate the statute against repeal are too high to make enactment of a moderate statute worthwhile.

This case is most likely to obtain (that is, the condition that $B-K_{E}<\lambda\left(C-K_{R}\right)$ is most likely to hold) when the benefits of the statute to its proponents are small relative to the enactment cost ( $B-K_{E}$ low), when the costs of the statute to its opponents are large relative to the repeal cost $\left(C-K_{R}\right.$ high), and when softening the impact of the statute on the opposition requires dissipating a large proportion of the benefits to supporters ( $\lambda$ high). So, speaking somewhat loosely, we might say that the statutes that fall into this category are those that transfer relatively small net benefits to proponents at a relatively high net cost to opponents, and cannot easily be modified to mitigate their redistributive effects. Precisely for these reasons, such statutes would not be enacted under a unitary system: they are too vulnerable to repeal to be worthwhile even to the party that would benefit from them.

Now consider what happens when we move from a unitary system $(\pi=0)$, to a SOP system in which $\pi=\pi^{*} \geq \bar{\pi}^{29}$ Under this system, if the first-period government is divided (or if Party $R$ has sole control), then, as before, no statute is enacted. However, if Party $L$ has unified control over the first-period government, it will enact an extreme statute. The reason is that the increase in the probability of second-period divided government reduces the likelihood of repeal, and this makes the enactment of an extreme statute sufficiently more attractive to Party $L$ that it would be willing to bear the opportunity cost of enactment.

Thus in this case the introduction of SOP institutions (such as bicameralism) has the coun-

\footnotetext{
${ }^{28}$ The assumptions that $\bar{\pi} \in(0,1)$ and that $B-K_{E}<\lambda\left(C-K_{R}\right)$ together imply that $p B<K_{E}$.

${ }^{29}$ The condition that $B-K_{E}<\lambda\left(C-K_{R}\right)$ implies that $\bar{\pi}=1-\frac{B-K_{E}}{(1-p) B}$.
} 
terintuitive effect of increasing the probability that the first-period government will enact the statute - this probability increases from 0 to $p\left(1-\pi^{*}\right)$. Of course, there is a $(1-p)\left(1-\pi^{*}\right)$ probability that this (extreme) statute will be repealed. Therefore, the shift from the unitary system to the SOP system increases the probability of a new law actually taking effect by a somewhat smaller amount-from 0 to $p\left(1-\pi^{*}\right)\left[1-(1-p)\left(1-\pi^{*}\right)\right]$. Nonetheless, in this case greater legislative fragmentation increases rather than decreases the probability of policy change. ${ }^{30}$

What about the effect of a shift from a unitary system $(\pi=0)$ to a SOP system $\left(\pi=\pi^{*} \geq \bar{\pi}\right)$ on the expected extremism of the legislative outcome? It follows immediately from the above discussion that, in the case where $B-K_{E}<\lambda\left(C-K_{R}\right)$, increasing $\pi$ from 0 to $\pi^{*}$ makes the expected legislative outcome more extreme (that is, more adverse to Party $R$ 's interests). Under the unitary regime, Party $L$ never enacts the statute, which gives Party $R$ a status quo payoff of 0 (the most moderate possible equilibrium outcome). However, under the SOP regime Party $L$ will enact an extreme statute if it secures unified control of the government; this imposes a policy cost of $C$ on Party $R$, unless Party $R$ manages to take sole control of the government in the second period and unilaterally repeals the statute. Thus under SOP the expected extremism of the legislative outcome (that is, the expected policy cost to Party $R$ ) is $p\left(1-\pi^{*}\right)\left[1-(1-p)\left(1-\pi^{*}\right)\right] C \geq 0$.

The preceding case is perhaps the starkest illustration of the model's central insight: under some circumstances, greater fragmentation of legislative powers can increase the frequency of legislation, leading to less moderate policy outcomes. The intuition, again, is that although an increase in $\pi$ reduces the probability of unified government, an increase in $\pi$ from a value less than $\bar{\pi}$ to a value greater than $\bar{\pi}$ will alter Party $L$ 's incentives such that a unified Left Party government in the first period will enact an extreme statute rather than retaining the status quo.

There is, however, a second case to consider. Suppose that $B-K_{E}>\lambda\left(C-K_{R}\right) \cdot{ }^{31}$ In this case, the net benefits of the statute to Party $L$ are large relative to the cost of modifying the statute to insulate it against future repeal. Loosely speaking, such statutes are those that produce large benefits to proponents at relatively modest cost to opponents $\left(B-K_{E}\right.$ large, $C$ small), those with significant repeal costs $\left(K_{R}\right.$ large), and/or those for which the compromises needed to mitigate the statute's adverse impact on opponents are not very costly to the statute's proponents ( $\lambda$ small).

\footnotetext{
${ }^{30}$ Note, however, that increasing $\pi$ from 0 up to any value just short of $\bar{\pi}$ will leave the probability of new legislation unchanged at 0 , while further increases in $\pi$ above $\bar{\pi}$ will reduce the probability that new legislation is enacted.

${ }^{31}$ This condition, coupled with the restriction to cases in which $\bar{\pi} \in(0,1)$, implies $\bar{\pi}=1-\frac{\lambda\left(C-K_{R}\right)}{(1-p) B}$.
} 
For statutes in this category, Party $L$ would rather make the necessary concessions to insulate the statute against repeal than leave the status quo in place. In this case, then, a unitary system $(\pi=0)$ produces legislative action: if Party $L$ controls the legislature, it will enact a moderate statute, which will be retained in the second period no matter which party is in power; if Party $R$ has the power to block the statute in the first period, then Party $L$ will either take no action (if $B-K_{E} \leq \lambda C$ ) or propose a consensus statute (if $B-K_{E}>\lambda C$ ), which Party $R$ would accept.

Under a SOP system in which $\pi=\pi^{*} \geq \bar{\pi}$, however, the outcome may be quite different. Under such a system, if Party $L$ has unified first-period control, it will enact an extreme statute rather than a moderate statute. The intuition, as before, is that if the probability of (future) divided government is high enough, then if Party $L$ enjoys unified government in the first period, it would be willing to risk enacting an extreme statute given the low probability of repeal. Repeal will nonetheless occur if Party $R$ secures unified control of the government in the second period. If Party $R$ can block legislation in the first period, then Party $L$ will either take no action or propose a consensus statute (depending on whether $B-K_{E}$ is less than or greater than $\lambda C$ ); either of these outcomes gives Party $R$ a net payoff of 0 .

In this case, then, a move from a unitary regime $(\pi=0)$ to a SOP regime $\left(\pi=\pi^{*} \geq \bar{\pi}\right)$ can reduce the frequency of legislative enactments, as the conventional account of legislative fragmentation predicts, but only if first-period divided government would produce inaction rather than a consensus statute (that is, only if $B-K_{E} \leq \lambda C$ ). More precisely, such a shift would reduce the probability that legislation is enacted from $p$ to $p\left(1-\pi^{*}\right)$, and would reduce the probability that new legislation is both enacted and retained from $p$ to $p\left(1-\pi^{*}\right)\left[1-(1-p)\left(1-\pi^{*}\right)\right]$. However, if divided government would produce a consensus statute (that is, if $B-K_{E}>\lambda C$ ), then a shift from a unitary system $(\pi=0)$ to a SOP system $\left(\pi=\pi^{*} \geq \bar{\pi}\right)$ will not reduce the probability that the government enacts a new statute in the first period, though it will reduce the total amount of legislation that is actually implemented. (The probability of first-period enactment in both cases is 1 , but the probability of second-period implementation drops from 1 to $1-p(1-p)\left(1-\pi^{*}\right)^{2}$.)

What about the expected extremism of the policy outcome? Under the unitary regime, the expected cost of the legislative outcome to Party $R$ is $p K_{R}$ (because with probability $p$ Party $L$ will unilaterally enact a moderate statute that gives Party $R$ a net payoff of $-K_{R}$ ). Under the SOP regime, the expected cost of the legislative outcome to Party $R$ (excluding the costs of 
pushing through a repeal) is $p\left(1-\pi^{*}\right)\left[1-(1-p)\left(1-\pi^{*}\right)\right] C$ (the probability that Party $L$ both has unified control in the first period and has the ability to block repeal in the second period, times the cost to Party $R$ of the extreme statute). Thus the expected extremism of the policy outcome is greater under the unitary system $(\pi=0)$ than under the SOP system $\left(\pi=\pi^{*} \geq \bar{\pi}\right)$ if but only if $(p-1)\left(\pi^{*}\right)^{2}+(1-2 p) \pi^{*}+\left(p-\frac{K_{R}}{C}\right)>0 .{ }^{32}$ Otherwise, the expected extremism of the policy outcome is actually higher under the SOP system, contrary to the conventional wisdom. Formally, if $B-K_{E}>\lambda\left(C-K_{R}\right)$, expected policy extremism is higher with $\operatorname{SOP}\left(\pi=\pi^{*} \geq \bar{\pi}\right)$ than with a unitary system $(\pi=0)$ if $\pi^{*} \in\left[\min \left\{1-\frac{\lambda\left(C-K_{R}\right)}{(1-p) B}, \frac{1}{1-p}\left(\frac{1}{2}-p-\sqrt{\frac{1}{4}-\frac{K_{R}}{2 C}}\right)\right\}, \frac{1}{1-p}\left(\frac{1}{2}-p+\sqrt{\frac{1}{4}-\frac{K_{R}}{2 C}}\right)\right) .33$

This interval is somewhat difficult to interpret, but it actually reflects a reasonably straightforward intuition. In order for policy extremism to be greater under SOP than under a unitary system, three things must be true about the probability of divided government under $\operatorname{SOP}\left(\pi^{*}\right)$. First, $\pi^{*}$ must be large enough that Party $L$ would prefer to enact an extreme statute rather than a moderate statute $\left(\pi^{*} \geq \bar{\pi}=1-\frac{\lambda\left(C-K_{R}\right)}{(1-p) B}\right)$. Second, $\pi^{*}$ must be large enough that expected extremism is higher if Party $L$ enacts a moderate statute rather than an extreme statute $\left(\pi^{*} \geq \frac{1}{1-p}\left(\frac{1}{2}-p-\sqrt{\frac{1}{4}-\frac{K_{R}}{2 C}}\right)\right)$. Third, $\pi^{*}$ must be small enough that the expected costs of such extremism to Party $R$ more than offset the decrease in the frequency with which Party $L$ has unified first-period control $\left(\pi^{*}<\frac{1}{1-p}\left(\frac{1}{2}-p+\sqrt{\frac{1}{4}-\frac{K_{R}}{2 C}}\right)\right.$. One can simplify this considerably with the admittedly restrictive assumption that $p=0.5$ (such that each party has an equal chance of securing unified government control). In that case, a shift from $\pi=0$ to $\pi=\pi^{*}$ increases expected extremism if but only if $\pi^{*} \in\left(1-\frac{2 \lambda\left(C-K_{R}\right)}{B}, \sqrt{1-\frac{2 K_{R}}{C}}\right)$.

To illustrate how greater separation of powers can increase expected policy extremism, consider a numerical example in which $p=0.5, B=4, K_{E}=2, C=2, K_{R}=0.5$, and $\lambda=1$. These values satisfy the condition that $B-K_{E}>\lambda\left(C-K_{R}\right)$ (because $\left.2>1.5\right)$. So, in a unitary system $(\pi=0)$, if Party $L$ has unified control of the first-period government (which occurs with probability 0.5), it will enact a moderate statute $(T=1.5)$, and this statute will always be retained in the second

\footnotetext{
${ }^{32}$ The left-hand side of this inequality is increasing in $\pi^{*}$ for all $\pi^{*}<\frac{2 p-1}{2(1-p)}$, and decreasing in $\pi^{*}$ for all $\pi^{*}>\frac{2 p-1}{2(1-p)}$. So, if $p \geq 0.5$, this expression is always decreasing in $\pi^{*}$, meaning that so long as $\pi^{*} \geq \bar{\pi}$, greater fragmentation of legislative power always reduces expected policy extremism. However, if $p<0.5$, there are values of $\pi^{*}$ such that even if $\pi^{*} \geq \bar{\pi}$, increasing the fragmentation of powers would increase the expected extremism of the policy outcome. The reason is that if $p$ is small, increasing the probability of divided government has a greater (negative) marginal effect on the probability that an extreme statute is repealed than on the probability that such a statute is enacted.

${ }^{33}$ If $2 K_{R}>C$, then there is no real solution to the expression for the upper bound of this interval (or for the second candidate for the lower bound); in that case, expected extremism is always maximized when $\pi=0$, as the conventional wisdom would predict.
} 
period. If Party $R$ can block legislation in the first period, then no statute will be enacted. Thus under a unitary regime Party $R$ 's expected policy payoff is $(0.5)(1.5-2)=-0.25$. Now consider a SOP system in which $\pi^{*}=0.5$ (that is, there is a 50 percent chance of divided government in each period). ${ }^{34}$ The numerical values above imply that $\bar{\pi}=0.25$. Because this value is smaller than 0.5, it follows that if Party $L$ has unified control in the first period (which occurs with probability $0.25)$, it will enact an extreme statute $(T=0)$, which will be retained in the second period with probability 0.75. If Party $L$ does not have sole first-period control, no statute will be enacted. The expected policy payoff to Party $R$ under the SOP regime is therefore $(0.25)(0.75)(-2)=-0.375$. In this example, the expected extremism of the policy outcome (that is, the expected policy cost to Party $R$ ) is greater with separation of powers than it is in a unitary system $(0.375>0.25)$.

The central result of the analysis can also be illustrated graphically, as in Figure 1. The case depicted in this figure uses the same values for $B, C, K_{E}, K_{R}$, and $\lambda$ as in the numerical example above. The $x$-axis is the degree of legislative fragmentation, $\pi$. The $y$-axis is the expected payoff to Party $R$, which can be thought of as a measure of expected policy moderation (lower values in the figure correspond to more extreme expected policy outcomes). Note that this value increases as $\pi$ increases from 0 to $\bar{\pi}$, and as $\pi$ increases from $\bar{\pi}$ to 1 . However, there is a discontinuous jump downward at $\pi=\bar{\pi}$, because at this point Party $L$ switches its first-period approach (in those cases where it has full control) from proposing a moderate policy to proposing an extreme policy.

\section{[FIGURE 1 ABOUT HERE]}

In sum, the preceding analysis shows that an increase in the fragmentation of legislative power can have (at least) two cross-cutting effects on policy stability and moderation. First, separation of powers increases the probability of divided government, which decreases the probability that the proponents of a statute will be able to enact it without significant concessions to opponents. All else equal, this effect implies that greater fragmentation of legislative power will reduce the frequency of legislation (that is, fragmentation increases stability) and/or will result in legislative outcomes that are less harmful to opposition interests (that is, fragmentation increases moderation). Second, precisely because separation of powers increases the probability of divided government, it also reduces the implicit threat that an extreme statute, if enacted, will be repealed at a later date.

\footnotetext{
${ }^{34}$ The parameter values $p=0.5$ and $\pi^{*}=0.5$ would correspond to a bicameral system in which each party has a 50-50 chance of winning control of each branch, with election results independent across branches and across time.
} 
This means that under a separation-of-powers system, if one party manages to secure unified control over all legislative institutions, that party is more likely to enact extreme statutes -implying less stability and/or less moderation than one would have observed under a unitary system.

These cross-cutting effects mean that the fragmentation of legislative power may not have a monotonic effect on either the expected stability or the expected moderation of government policy. Furthermore, the second of these two effects - the one that implies a negative correlation between separation of powers and the moderation or stability of policy outcomes - is most pronounced for (loosely speaking) "intermediate" levels of separation of powers. A consociational system, or something close to it, is indeed likely to produce either legislative inertia or broad consensus statutes. But lesser degrees of legislative fragmentation - in which there is a substantial probability of divided government but also a substantial probability of unified government-may relax the constraint induced by the implicit threat of repeal without a fully offsetting reduction in the probability that one party or faction will have the opportunity to implement its preferred legislative initiatives.

\section{Discussion}

The preceding analysis has very different empirical implications than the more familiar hypothesis that greater separation of legislative powers tends (monotonically) to produce greater stability and policy moderation. As discussed above, the model developed here predicts that - at least for certain kinds of statutes - unitary systems (with a very low level of legislative fragmentation) and consociational systems (or, more generally, systems with a very high level of legislative fragmentation) should exhibit more stability and/or compromise, while systems with an intermediate degree of legislative fragmentation should exhibit a different pattern, with periods of inactivity punctuated by occasional bursts of relatively extreme statutory redistribution, which then persist for substantial periods of time before eventual repeal or modification.

Moreover, the model offers some guidance as to the types of statutes for which this nonmonotonic relationship between legislative fragmentation and policy stability/moderation is more likely. In particular, in order for this non-monotonicity result to hold, the implicit threat of repeal must be substantial enough that it would affect the behavior of a party or interest group that manages to secure temporary control of the legislative branch(es). If there is no significant 
repeal threat - if, for example, the cost of repeal is very high, or if the party in power and its principal supporters care overwhelmingly about short-term rather than long-term policy effectsthen each party would always push through the most extreme proposal it can enact. In that case, the only constraint on policy extremism would be at the enactment stage, and the conventional wisdom - that separation of legislative power encourages stability and moderation-would hold. The non-monotonicity highlighted by this paper is most likely for statutes which provide substantial long-term benefits to supporters (making insulation against repeal a priority for proponents) but impose substantial costs on opponents (making the threat of repeal credible). In other words, the kinds of statutes for which the analysis in this paper is most likely to apply are those with the greatest redistributive potential - and such statutes, at least on some accounts, are precisely the ones that should be of greatest concern from the perspective of an institutional designer.

Of course, whether the implicit threat of repeal in fact affects legislative behavior in the way the model suggests is an empirical question, and this empirical question is very difficult to answer given limitations of the existing data. Nonetheless, there is some suggestive evidence that dynamics of the sort predicted by the model are plausible. First, at least in the U.S. federal system, despite the common misperception that government programs are "immortal," repeals or major revisions of the statutes that create such programs (including redistributive programs) are in fact fairly common (Berry, Burden and Howell 2010; Corder 2004; Maltzman and Shipan 2008; Ragusa 2010). This implies that rational lawmakers and interest groups would take the threat of repeal seriously. Moreover, consistent with the model's predictions (and unsurprisingly) repeals are more likely following a change in the partisan control of the government (Berry, Burden and Howell 2010), but - also consistent with the model's predictions - repeals are less likely during periods of divided government (Ragusa 2010). ${ }^{35}$

\footnotetext{
${ }^{35}$ As noted above, partisan unity or division may not correlate perfectly with the sort of unity or division that is relevant here, but it its likely somewhat correlated.

Any discussion of relative legislative productivity under unified versus divided government in the U.S. must of course acknowledge the seminal work of Mayhew (1991), who found that the federal government produces as many major laws in periods of divided government as it does in periods of unified government (see also Mayhew (2005)). A strong interpretation of Mayhew's (much debated) finding - that divided government has no effect on legislative output - would pose a challenge to the empirical validity of both the model presented in this paper and the more conventional view that separation of powers promotes stability. However, it is possible that the consistency in the quantity of legislative output masks significant variation in the content of that output. In particular, the model presented here predicts that first-period divided government would block the enactment of certain statutes, but in other cases first-period divided government would produce "consensus" statutes. If the total number of potential proposals that would produce a consensus statute is larger than the legislative "budget constraint" in each period, then divided government might produce a similar number of major laws to what one observes under unified government,
} 
The available evidence is somewhat more mixed on whether - as the model predicts - legislation passed by unified government is more extreme, and thus more vulnerable to repeal. Unfortunately, the lack of good objective measures makes it difficult to compare levels of "extremism" or "moderation." Nonetheless, there is some suggestive evidence from the U.S. federal system that is broadly consistent with the model's predictions, in that legislation passed by unified governments is more likely (relative to legislation passed under divided government) to pass on party-line votes (Thorson 1998) and to address "major" issues (Binder 1999). Party-line votes on significant issues suggest, though of course do not establish, more extreme redistribution. As for whether legislation adopted by unified governments is more vulnerable to repeal, although some preliminary empirical research on this point suggested the opposite (Maltzman and Shipan 2008), more recent research has found that legislation enacted under divided government is indeed more durable than legislation enacted under unified government (Ragusa 2010), which again is broadly consistent with the model's predictions (though certainly not conclusive).

The available evidence on whether systems with greater fragmentation of legislative power exhibit greater stability and/or policy moderation is mixed. While some cross-country research finds that systems with more legislative veto players produce fewer new laws (Henisz 2004; Tsebelis 2002), other research looking at within-jurisdiction variation in systems that altered their legislative process finds no significant effect (Rogers 2003). The former set of findings may appear more consistent with the conventional wisdom than with the predictions of the model presented in this paper. However, in addition to generic concerns about this sort of empirical analysis (such as the endogeneity of institutional choices and the difficulty of developing measures of legislative fragmentation that are consistent and comparable across systems), the relevant cross-country research typically uses linear regression models that would obscure non-monotonic effects of the sort predicted by the theoretical analysis developed in this paper. Furthermore, the existing literature typically focuses on the more easily measured quantity of legislative output (that is, policy stability), rather than its distributive implications (that is, moderation).

Thus while a rigorous investigation of the model's empirical predictions is beyond the scope of this paper, much (though admittedly not all) of the available quantitative evidence is broadly but these laws would be much different (with smaller redistributive effects). That interpretation is consistent with at least some of the research sparked by Mayhew's pioneering work (Coleman 1999; Howell et al. 2000; Thorson 1998). 
consistent with the model's principal assumptions and predictions. None of this is dispositive, and this paper makes no claim that the non-monotonicity identified as a possibility by the theoretical analysis is in fact empirically significant. The more modest claim is that nothing in the existing empirical literature provides a sufficient reason to reject this possibility out of hand, and the model's predictions ought to be explicitly compared to the predictions of the more conventional hypotheses about the separation of powers, to the extent that the data allow such comparisons.

If it turns out that the main theoretical predictions of the model are accurate - if the separation of legislative power indeed has a non-monotonic effect on legislative stability and moderation, such that greater legislative fragmentation may sometimes lead to more, and more extreme, statutory enactments - then this could have ramifications for a number of important settings in which positive political theory findings are applied to consequential political decisions.

First, beliefs about the impact of separation of powers on legislative output may affect decisions about constitutional design. While the main features of the U.S. Constitution (particularly its legislative institutions) have proven remarkably durable, the wave of constitution-making and constitution-revising around the world over the past generation has highlighted the fact that in many countries basic issues of constitutional structure have contemporary and ongoing salience. Indeed, ideas about the separation of powers, including those traditionally attributed to the Framers of the U.S. Constitution (and often propounded by U.S. consultants and advisors), have allegedly played a role in some of these contemporary cases of constitutional drafting and reform (deLisle 1999; Robinson 1992; Schwartz 2009; Siegan 1994) (but see Tushnet (2008)).

Second, even when changes to the basic constitutional structure are off the table - as they probably are in the United States, at least in the short-to-medium term - there are numerous smaller-scale institutional design choices that bear directly on the degree of legislative fragmentation (Vermeule 2007). This category might include debates over the filibuster (Alter and McGranahan 2000; Wawro and Schickler 2006), as well as proposals for super-majority rules in other contexts (McGinnis and Rappaport 1999; Garrett 1999). A parallel analysis might also apply to the regulatory process, where non-constitutional choices about administrative procedure affect the degree to which a particular administration or interest group can secure or block changes in regulatory policy (Givati and Stephenson 2011; McCubbins, Noll and Weingast 1989; McGarity 1992).

Third, beliefs about the intent and effect of constitutional provisions pertaining to separation 
of powers may affect judicial approaches to both constitutional and statutory interpretation. In the constitutional context, beliefs about the intent or purpose of a constitution's separation-ofpowers provisions may influence how judges interpret and enforce those provisions (Clark 2001; Eskridge and Ferejohn 1992; Strauss 1987). In the statutory context, many prominent scholars and jurists have argued that judges should adopt interpretive methods that reinforce the purposes of the constitutional lawmaking structure, including stability and compromise (Easterbrook 1983, 1994; Manning 2001, 2007); others have argued for different, more flexible interpretive methods, precisely because the constitutional lawmaking scheme is thought to produce excessive stasis otherwise (Breyer 1992; Calabresi 1982; Eskridge 1988).

This paper takes no position on the normative implications of the positive analysis. Even if future research empirically substantiates the model's predictions-including the counter-intuitive finding that increasing legislative fragmentation can sometimes reduce rather than increase both policy stability and policy moderation - this would not necessarily bolster or undermine the case for such fragmentation. Such a finding would, however, substantially revise the terms of the normative debate. If stability, moderation, and compromise are desirable, then in some situations a polity might be better off concentrating legislative power, perhaps by reducing the number of veto players or facilitating their circumvention. If the polity is plagued by excessive stasis, or if it would be socially desirable for elected representatives to pursue bold but controversial policy initiatives with long-term effects, then greater separation of legislative power might be a good thing, precisely because it attenuates the implicit threat of repeal that hangs over every such initiative. Moreover, the non-monotonicity highlighted by the model implies that prescriptive advice must be more nuanced and context-specific: if one wants to increase (or decrease) stability and moderation, one cannot know whether greater fragmentation of legislative power will help or hurt unless one can make a plausible conjecture about which part of the parameter space the polity currently occupies.

\section{Conclusion}

This paper developed a simple formal model that calls into question the conventional wisdom that greater separation of powers leads to greater policy stability (that is, fewer changes from the status quo) and greater policy moderation (that is, policies that involve less extreme redistribution from 
"losers" to "winners"). This conventional wisdom is based on the eminently reasonable conjecture that greater separation of powers increases the expected number of parties or interest groups with the ability to veto any new legislative proposal. When many groups have a veto, proponents of the new legislation must buy them off by making concessions. Sometimes, though, it is impossible or not worthwhile for proponents to make sufficient concessions to secure enactment, in which case the status quo will persist even though a statute might have passed if legislative power were more concentrated.

This conventional analysis is not wrong, but it overlooks a second consideration: parties and interest groups care about insulating favorable legislation against future repeal, and the same separation-of-powers institutions that make enactment difficult also make repeal difficult. It follows that an increase in the fragmentation of legislative power (for example, due to an increase in the number of veto players, or to the imposition of a super-majority voting rule) will have two crosscutting effects on the stability and moderation of policy outcomes. On the one hand, greater fragmentation makes it more difficult for any one faction to push through extreme legislation. On the other hand, greater fragmentation attenuates the threat of repeal, which gives a faction that finds itself able to push through extreme legislation a stronger incentive to do so, rather than to enact a more moderate statute. The result, at least for certain types of statute, is a non-monotonic relationship between the fragmentation of legislative power and the stability and moderation of legislative policy. In unitary systems, the government is institutionally unconstrained at the time of enactment, but the implicit threat of repeal may induce inaction or compromise. For "intermediate" levels of legislative fragmentation, the implied threat of repeal is no longer sufficient to deter a unified government from enacting extreme policies, but unified governments still occur with sufficient frequency that the polity enacts such extreme policies relatively often. For high levels of fragmentation, where each major interest group is essentially guaranteed a veto, policy is likely to be both very stable and very moderate, in that only consensus statutes can ever pass.

It remains an open question whether this theoretical prediction is empirically significant. That said, many basic features of the model, as well as important aspects of the model's predictions, are broadly consistent with the admittedly scant existing empirical evidence. If the theoretical argument sketched here turns out to be more accurate than the theoretical conjecture sketched by the Framers of the U.S. Constitution and the modern social scientists who have followed them, 
then many familiar arguments - not only in academic analysis, but in practical debates over constitutional design, institutional reform, and jurisprudence - may need substantial revision.

\section{References}

Ackerman, Bruce. 2000. "The New Separation of Powers." Harvard Law Review 113:633-729.

Ackerman, Bruce and William T. Hassler. 1981. Clean Coal/Dirty Air. New Haven: Yale University Press.

Alesina, Alberto. 1987. "Macroeconomic Policy in a Two-Party System as a Repeated Game." Quarterly Journal of Economics 102(3):651-678.

Alesina, Alberto and Howard Rosenthal. 1995. Partisan Politics, Divided Government, and the Economy. New York: Cambridge University Press.

Alter, Alison B. and Leslie Moscow McGranahan. 2000. "Reexamining the Filibuster and Proposal Powers in the Senate." Legislative Studies Quarterly 25(2):259-284.

Arnold, R. Douglas. 1990. The Logic of Congressional Action. New Haven: Yale University Press.

Baron, David P. 1996. "A Dynamic Theory of Collective Goods Programs." American Political Science Review 90:316-330.

Baron, David P. and John A. Ferejohn. 1989. "Bargaining in Legislatures." American Political Science Review 83(4):1181-1206.

Berry, Christopher R., Barry C. Burden and William G. Howell. 2010. "After Enactment: The Lives and Deaths of Federal Programs." American Journal of Political Science 54(1):1-17.

Berry, Christopher R. and Jacob E. Gersen. 2008. "The Unbundled Executive." University of Chicago Law Review 75:1385-1434.

Binder, Sarah A. 1999. "The Dynamics of Legislative Gridlock, 1947-96." American Political Science Review 93(3):519-533. 
Breyer, Stephen G. 1992. "On the Uses of Legislative History in Interpreting Statutes." Southern California Law Review 65:845-874.

Buchanan, James M. and Gordon Tullock. 1962. The Calculus of Consent: The Logical Foundations of Constitutioal Democracy. Ann Arbor: University of Michigan Press.

Calabresi, Guido. 1982. A Common Law for the Age of Statutes. Cambridge: Harvard University Press.

Calabresi, Steven G. 2001. "Why Professor Ackerman Is Wrong To Prefer the German to the U.S. Constitution." Constitutional Commentary 18:51-104.

Cameron, Charles. 2000. Veto Bargaining: Presidents and the Politics of Negative Power. New York: Cambridge University Press.

Clark, Bradford R. 2001. "Separation of Powers as a Safeguard of Federalism." Texas Law Review 79:1321-1459.

Coate, Stephen and Stephen Morris. 1999. "Policy Persistence." American Economic Review 89(5):1327-1336.

Coleman, John J. 1999. "Unified Government, Divided Government, and Party Responsiveness." American Political Science Review 93(4):821-835.

Cooter, Robert D. 2000. The Strategic Constitution. Princeton: Princeton University Press.

Corder, J. Kevin. 2004. "Estimating the Hazard of Program Termination." American Politics Research 32(1):3-25.

Cox, Gary W. and Mathew D. McCubbins. 2001. The Institutional Determinants of Economic Policy Outcomes. In Presidents, Parliaments, and Policy, ed. Stephen Haggard and Mathew D. McCubbins. New York: Cambridge University Press pp. 21-63.

Crain, W. Mark and Robert D. Tollison. 1979. "The Executive Branch in the Interest-Group Theory of Government." Journal of Legal Studies 8(3):555-567. 
Cutrone, Michael and Nolan McCarty. 2006. Does Bicameralism Matter? In The Oxford Handbook of Political Economy, ed. Barry R. Weingast and Donald Wittman. New York: Oxford University Press pp. 180-105.

Dahl, Robert. 1956. A Preface to Democratic Theory. Chicago: University of Chicago Press.

de Figueiredo, Rui J.P. 2002. "Electoral Competition, Political Uncertainty, and Policy Insulation." American Political Science Review 96(2):321-333.

deLisle, Jacques. 1999. "Lex Americana?: United States Legal Assistance, American Legal Models, and Legal Change in the Post-Communist World and Beyond." University of Pennsylvania Journal of International Economic Law 20:179-308.

Easterbrook, Frank H. 1983. "Statutes' Domains." University of Chicago Law Review 50:533-552.

Easterbrook, Frank H. 1994. "Text, History, and Structure in Statutory Interpretation." Harvard Journal of Law and Public Policy 17:61-70.

Elhauge, Einer R. 1991. "Does Interest Group Theory Justify More Instrusive Judicial Review?" Yale Law Journal 101:31-110.

Ely, John Hart. 1980. Democracy and Distrust: A Theory of Judicial Review. Cambridge: Harvard University Press.

Eskridge, William N., Jr. 1988. "Spinning Legislative Supremacy.” Georgetown Law Journal 78:319352.

Eskridge, William N., Jr. and John Ferejohn. 1992. "The Article I, Section 7 Game.” Georgetown Law Journal 80:523-564.

Farrand, Max, ed. 1966. The Records of the Federal Convention of 178\%. Vol. 3 New Haven: Yale University Press.

Ferejohn, John and Charles R. Shipan. 1990. "Congressional Influence on Bureaucracy." Journal of Law, Economics, and Organization 6(Special Issue):1-20.

Fiorina, Morris P. 1999. "Whatever Happened to the Median Voter?" Unpublished manuscript, Stanford University. 
Fox, Justin and Richard Van Weelden. 2010. "Partisanship and the Effectiveness of Oversight." Journal of Public Economics 94(9-10):674-687.

Garrett, Elizabeth. 1999. "A Fiscal Constitution with Supermajority Voting Rules." William and Mary Law Review 40:471-504.

Garrett, Elizabeth. 2008. "Framework Legislation and Federalism." Notre Dame Law Review $83: 1495-1538$.

Garry, Patrick N. 2008. An Entrenched Legacy: How the New Deal Constitutional Revolution Continues to Shape the Role of the Supreme Court. University Park: Pennsylvania State University Press.

Gersen, Jacob E. and Eric A. Posner. 2007. "Timing Rules and Legal Institutions." Harvard Law Review 121:543-589.

Givati, Yehonatan and Matthew C. Stephenson. 2011. "Judicial Deference to Inconsistent Agency Statutory Interpretations." Journal of Legal Studies 40(1):85-113.

Glaeser, Edward L., Giacomo A.M. Ponzetto and Jesse M. Shapiro. 2005. "Strategic Extremism: Why Republicans and Democrats Divide on Religious Values." Quarterly Journal of Economics 120(4):1283-1330.

Hammond, Thomas H. and Jack H. Knott. 1996. "Who Controls the Bureaucracy?: Presidential Power, Congressional Dominance, Legal Constraints, and Bureaucratic Autonomy in a Model of Multi-Institutional Policymaking." Journal of Law, Economics, and Organization 12(1):121-168.

Henisz, Witold J. 2004. "Political Institutions and Policy Volatility." Economics and Politics 16(1):1-27.

Horn, Murray J. and Kenneth A. Shepsle. 1989. "Administrative Process and Organizational Form as Legislative Responses to Agency Costs." Virginia Law Review 75:499-508.

Howell, William, Scott Adler, Charles Cameron and Charles Riemann. 2000. "Divided Government and the Legislative Productivity of Congress, 1945-94." Legislative Studies Quarterly 25(2):285312. 
Kagan, Elena. 2001. "Presidential Administration." Harvard Law Review 114:2245-2385.

Krehbiel, Keith. 1996. "Institutional and Partisan Sources of Gridlock." Journal of Theoretical Politics 8(1):7-40.

Krehbiel, Keith. 1998. Pivotal Politics: A Theory of U.S. Lawmaking. Chicago: University of Chicago Press.

Landes, William M. and Richard A. Posner. 1975. "The Independent Judiciary in an Interest Group Perspective." Journal of Law and Economics 18(3):875-901.

Landis, James M. 1936. The Administrative Process. New Haven: Yale University Press.

Levinson, Sanford. 2006. Our Undemocratic Constitution: Where the Constitution Goes Wrong (and How We the People Can Correct It). New York: Oxford University Press.

Lewis, David E. 2003. Presidents and the Politics of Agency Design. Palo Alto: Stanford University Press.

Lijphart, Arend. 1977. Democracy in Plural Societies: A Comparative Exploration. New Haven: Yale University Press.

Macedo, Stephen. 2009. "Our Imperfect Democratic Constitution: The Critics Examined." Boston University Law Review 89:609-628.

Maltzman, Forrest and Charles R. Shipan. 2008. "Change, Continuity, and the Evolution of the Law." American Journal of Political Science 52(2):252-267.

Manning, John F. 2001. "Textualism and the Equity of the Statute." Columbia Law Review 101:1127.

Manning, John F. 2007. "Lawmaking Made Easy." Green Bag 10:191-204.

Mayhew, David. 1974. Congress: The Electoral Connection. New Haven: Yale University Press.

Mayhew, David R. 1991. Divided We Govern: Party Control, Lawmaking, and Investigations, 1946-1990. New Haven: Yale University Press. 
Mayhew, David R. 2005. Divided We Govern: Party Control, Lawmaking, and Investigations, 1946-2002. 2 ed. New Haven: Yale University Press.

McCarty, Nolan. 2000. "Proposal Rights, Veto Rights, and Political Bargaining." American Journal of Political Science 44(3):506-522.

McCubbins, Mathew D., Roger G. Noll and Barry R. Weingast. 1987. "Administrative Procedures as Instruments of Political Control." Journal of Law, Economics, and Organization 3(2):243-277.

McCubbins, Mathew D., Roger G. Noll and Barry R. Weingast. 1989. "Structure and Process, Politics and Policy: Administrative Arrangements and the Political Control of Agencies." Virginia Law Review 75:431-482.

McGann, Anthony. 2006. The Logic of Democracy: Reconciling Equality, Deliberation, and Minority Protection. Ann Arbor: University of Michigan Press.

McGarity, Thomas O. 1992. "Some Thoughts on 'Deossifying' the Rulemaking Process." Duke Law Journal 41:1385-1462.

McGinnis, John O. and Michael B. Rappaport. 1999. "Supermajority Rules as Constitutional Solution." William and Mary Law Review 40:365-470.

McGinnis, John O. and Michael B. Rappaport. 2002. "Our Supermajoritarian Constitution." Texas Law Review 80:703-806.

McGinnis, John O. and Michael B. Rappaport. 2006. "The Judicial Filibuster, the Median Senator, and the Countermajoritarian Difficulty." Supreme Court Review 2005:257-305.

Mebane, Walter R., Jr. 2000. "Coordination, Moderation, and Institutional Balancing in American Presidential and House Elections." American Political Science Review 94:37-57.

Mebane, Walter R., Jr. and Jasjeet S. Sekhon. 2002. "Coordination and Policy Moderation at Midterm." American Political Science Review 96(1):141-157.

Miller, Nicholas R. 1983. "Pluralism and Social Choice." American Political Science Review $77(3): 734-747$. 
Moe, Terry M. 1989. The Politics of Bureaucratic Structure. In Can the Government Govern?, ed. John E. Chubb and Paul E. Peterson. Washington, D.C.: Brookings.

Moe, Terry M. 1990. The Politics of Structural Choice: Towards a Theory of Public Bureaucracy. In Organization Theory: From Chester Barnard to the Present and Beyond, ed. Oliver E. Williamson. Berkeley: University of California Press.

Moe, Terry M. and Michael Caldwell. 1994. "The Institutional Foundations of Democratic Government: A Comparison of Presidential and Parliamentary Systems." Journal of Institutional and Theoretical Economics 150(1):171-195.

Moe, Terry M. and William G. Howell. 1999. "The Presidential Power of Unilateral Action." Journal of Law, Economics, and Organization 15(1):132-179.

Myers, Richard E., II. 2008. "Responding to the Time-Based Failures of the Criminal Law Through a Criminal Sunset Amendment." Boston College Law Review 49:1327-1382.

Penn, Elizabeth Maggie. 2009. "A Model of Farsighted Voting." American Journal of Political Science 53(1):36-54.

Persson, Torsten, Gerard Roland and Guido Tabellini. 1997. "Separation of Powers and Political Accountability." Quarterly Journal of Economics 112(4):310-327.

Pierson, Paul, ed. 2001. The New Politics of the Welfare State. Oxford: Oxford University Press.

Ragusa, Jordan Michael. 2010. "The Lifecycle of Public Policy: An Event History Analysis of Repeals to Landmark Legislative Enactment, 1951-2006." American Politics Research 38(6):10151051.

Riker, William H. 1992. "The Merits of Bicameralism." International Review of Law and Economics $12(2): 166-168$.

Robinson, Donald L. 1992. "The Comparative Study of Constitutions: Suggestions for Organizing the Inquiry." PS: Political Science and Politics 25(2):272-280.

Rogers, James R. 2003. "The Impact of Bicameralism on Legislative Production." Legislative Studies Quarterly 28(4):509-528. 
Schwartz, Victoria. 2009. "The Influences of the West on the 1993 Russian Constitution." Hastings International and Comparative Law Review 32:101-153.

Shepsle, Kenneth A. and Barry R. Weingast. 1987. "The Institutional Foundations of Committee Power." American Political Science Review 81(1):85-104.

Siegan, Bernard H. 1994. Drafting a Constitution for a Nation or Republic Emerging into Freedom, 2nd Edition. 2 ed. Fairfax: George Mason University Press.

Stephenson, Matthew C. 2003. "When the Devil Turns...': The Political Foundations of Independent Judicial Review." Journal of Legal Studies 32(1):50-89.

Stephenson, Matthew C. and Jide O. Nzelibe. 2010. "Political Accountability Under Alternative Institutional Regimes." Journal of Theoretical Politics 22(2):139-167.

Strauss, Peter L. 1987. "Formal and Functional Approaches to Separation-of-Powers Questions-A Foolish Inconsistency?" Cornell Law Review 72:488-526.

Sunstein, Cass R. 1985. "Interest Groups in American Public Law." Stanford Law Review 38:29-87.

Sunstein, Cass R. 1993a. After the Rights Revolution: Reconceiving the Regulatory State. Cambridge: Harvard University Press.

Sunstein, Cass R. 1993b. The Partial Constitution. Cambridge: Harvard University Press.

Thorson, Gregory R. 1998. "Divided Government and the Passage of Partisan Legislation, 19471990." Political Research Quarterly 51(3):751-764.

Tsebelis, George. 2002. Veto Players: How Political Institutions Work. Princeton: Princeton University Press.

Tsebelis, George and Jeanette Money. 1997. Bicameralism. Cambridge: Cambridge University Press.

Tushnet, Mark. 2008. "Some Skepticism about Normative Constitutional Advice." William and Mary Law Review 49:1473-1495. 
Vermeule, Adrian. 2007. Mechanisms of Democracy: Institutional Design Writ Small. New York: Oxford University Press.

Vlaicu, Razvan. 2008. "Executive Performance under Direct and Hierarchical Accountability Structures: Theory and Evidence." Unpublished Paper.

Wawro, Gregory J. and Eric Schickler. 2006. Filibuster: Obstruction and Lawmaking in the U.S. Senate. Princeton: Princeton University Press. 
Figure 1: Expected Payoff to Party R from Party L's Proposed Statute, as a Function of Legislative Fragmentation $\left(p=0.5, B=4, C=2, K_{E}=2, K_{R}=0.5, \lambda=1\right)$

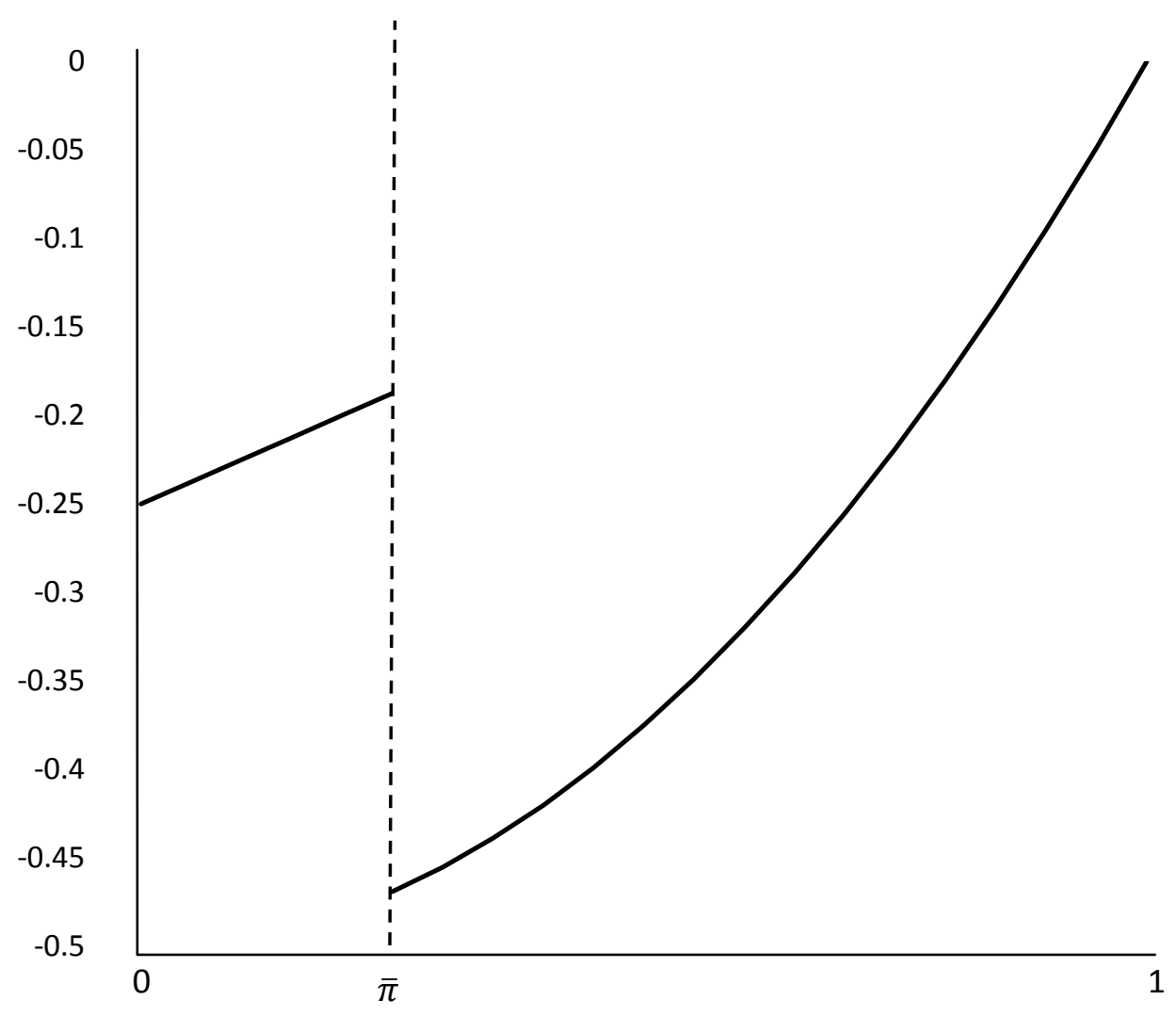

Fragmentation of Lawmaking Power $(\pi)$ 